\title{
SYNONYMICAL AND OTHER NOTES ON DIPTERA.
}

\author{
By W. R. Thompson. \\ Bureau of Entomology, U. S. Dept. of Agriculture.
}

I.

In Vol. II, No. 4 of the "Annals of the Entomological Society of America," a number of species and genera of North American Tachinids are described as new by Mr. C. H. T. Townsend. While working in the National Museum some time ago, I had occasion to make a careful study of the types of some of these forms, with the results given herewith.

Paragermaria autumnalis Towns.

This species has been described by Mr. D. W. Coquillett in Proc. Ent. Soc. Wash., VI., p. 186, 1904, as Distichona auriceps. The species is a well-marked one and there can be no question as regards the specific synonymy. The question of the synonymy of the three genera Distichona v. d. Wulp, Pseudogermaria B. \& B., and Mr. Townsend's new genus Paragermaria, is a more difficult one and $I$ do not care to express an opinion upon it at the present time. It must be noted, however, that in the specimens of this species which I have examined, there are a couple of hairs below the lowest frontal bristles and a row of similar fine hairs extends up the parafacials to a short distance below the upper ones just mentioned so that the parafacials cannot be termed bare. On this account Distichona auriceps Coqt., will not run to the genus Distichona in either the key to the genera in Mr. Coquillett's "Revision," nor in Mr. Adams' in Williston's "Manual," but will run out to Winthemia, from which it is easily distinguished by the reclinate ocellar bristles, the ciliate facial ridges, the broad cheeks, etc.

Sisyropa hemerocampae Towns.

Mr. Townsend gives as a synonym of this species, Exorista griseomicans Coq. (non v. d. Wulp), but has apparently over- 
looked the fact that what is apparently the same form has been described already by Mr. Coquillett in the "Revision of the Tachinidæ," pp. 97-98, as Exorista amplexa. An examination of the series of specimens referred by Mr. Coquillett in the "Revision," to griseomicans $\mathrm{v}$. d. Wulp, of those described by him as amplexa, and of the specimens included by Mr. Townsend under hemerocampor, has disclosed the fact that the number of post-sutural macrochætæ is variable within the species, many specimens having three post-suturals on one side and four on the other. No other differences between the three forms are perceptible and consequently they must be referred to one and the same species. It is doubtful if the species is the one described by van der Wulp in the Biologia as griseomicans. His description omits several of the important characters but the legs are described as "black" whereas in all of the specimens of this form which I have examined, the tibiæ and often the femora as well, are reddish-yellow. Until it can be positively determined by an examination of van der Wulp's type that the species are not distinct the synonomy must stand as follows:

\section{Exorista amplexa Coqt.}

1897. E. amplexa Coqt., in Revision of the Tachinidæ, pp. 97-98.

E. griseomicans Coqt. (non van der Wulp), loc. cit., p. 98.

1909. Sisyropa hemerovampa Towns., in Ann. Am. Ent. Soc., Vol. II, no. 4, p. 248.

Mr. Townsend gives no reasons for referring the species to the genus Sisyropa and until such reasons are forthcoming it must remain in the genus Exorista.

Eumasicera coccidella Towns.

The type of this species, which is a single female from Massachusetts, agrees perfectly with types and co-types of Sturmia sternalis Coqt., described from Missouri, and the forms seem to be without doubt identical. The genus Eumasicera certainly cannot stand since the species runs to the genus Sturmia in Mr. Townsend's own key to the genus Argyrophylax and its allies, in the "Taxonomy of the Muscoidean Flies," p. 98.

Rileyella Towns. 
This genus is proposed by Mr. Townsend to include a single species,-Frontina aletice Riley, and as I understand it, to separate this form from Frontina frenchii Will., and $F$. archippivora Will., both of which have marginal macrochætæ on the first two abdominal segments in both sexes. After a careful comparison of the characters afforded by the puparia, which it may be remarked, are frequently of great assistance in the study of the Tachinidæ, and of the adult characters, including those afforded by the genitalia of the males, I have come to the conclusion that there is no good reason for the generic separation of aletice and frenchii. In the "Taxonomy of the Muscoidean Flies," p. 88, Mr. Townsend himself included aletice in the same genus with hesperus B. and B. which Mr. Coquillett in his "Revision" gives as a synonym of frenchii.

\section{Cordyligaster septentrionalis Towns.}

This form, described by Mr. Townsend from specimens from Plummer's Island, Md., is evidently $C$. minuscula v. d. Wulp, which was described from various localities in Mexico. A long series of specimens of this species is in the U. S. N. M. collections, and a careful study of the series and comparison with the types and co-types of Mr. Townsend's species, failed to disclose any specific differences. The description given by Mr. Townsend differs very little from that given by van der Wulp in the Biologia Centrali Americana, and there can be no doubt as to the specific identity of the two forms.

In the "Taxonomy of the Muscoidean Flies," p. 80, Mr. Townsend has described a new genus and species, Oedemasoma nuda, from a male specimen collected in Nevada, and remarks upon its close resemblance to Wahlbergia brevipennis Loew, to which Mr. Coquillett had referred this specimen with a query. The only differences which Mr. Townsend was able to find were slight differences in the position of the hind cross-vein, in the length of the petiole of the apical cell, and in the distribution of the pollen on the head and thorax. Through the kindness of Mr. Samuel Henshaw, I have been able to examine Loew's type in the Museum of Comparative Zoology in Cambridge. To all appearances Loew's type is somewhat greased, which undoubtedly accounts for the absence of the slight silvery pruinosity on the parafrontals 
and anterior part of the mesonotum which Mr. Townsend describes as present in Oedemasoma nuda. Loew's specimen is a female whereas Mr. Townsend's is a male. In view of these facts it seems scarcely reasonable to separate them specifically. At Mr. Coquillett's request I drew up a description of the type of Wahlbergia brevipennis Loew, and forwarded it to him for comparison with the type of Oedemasoma nuda Towns., and he has come to the conclusion that the differences in the sex of the two specimens and the greased condition of Loew's type were sufficient to account for the differences which exist between them. Mr. Coquillett considers that the generic reference to Wahlbergia was correct, so that the generic synonymy will stand as follows:

Besseria Desvoidy, 1830.

Wahlbergia Zetterstedt, 1842.

Apostrophas Loew, 1870.

Oedemasoma Townsend, 1908.

In the other questions of synonymy discussed above Mr. Coquillett substantially agrees with me, and I wish to express my gratitude to him for his kind and courteous assistance in this and many other matters.

II.

In the keys to the genera of the Sarcophagidæ and Muscidæ in Williston's "Manual” there exists a slight but misleading error to which it may be well to call attention. If I do not mistake, these keys are adapted from those drawn up by Brauer and v. Bergenstamm in "Die Zweiflügler des k. k. Museums zu Wien." As Mr. Townsend has already pointed out in his "Taxonomy," the "genæ" or "Wangen" of Brauer and v. Bergenstamm do not correspond to the "cheeks," as the latter term is commonly understood, and as it is used in the keys to the Tachinidæ and Dexiidæ in the "Manual," but correspond to the "sides of the face" or "parafacials." The differences between the genera Calliphora and Lucilia, and between Phormia and Protocalliphora, are not in the presence or absence of hairs on the cheeks but on the sides of the face. Therefore, on page 343 of Williston's "Manual," the words "sides of the face," or "parafacials" should be substituted for "cheeks," in lines $2,5,8$ and 11, and the same correction should be made on page 351 , lines 4 , and 5 . 


\section{PUBLICATIONS FOR SALE}

\section{By the Cambridge Entomological Club.}

Orders, accompanied by remittances, should be sent to C. T. Brues, Bussey Institution, Forest Hills, Boston, Mass.

\section{Psyche.}

Vols. 1-2; Vols. 5-10, each, $\$ 3.00$.

Vols. 11-16, each $\$ 1.00$.

The following articles, originally published in Psyche, are to be had separately, at the prices indicated:

\section{Lepidoptera.}

Anon. On the Relation between European and American Noctuina. 4 pp., 1875,

Beutenmuller, W. Descriptions of some New North American Moths. 3 pp., 1890,

Chambers, V. T. The Classification of the Tineidæ. 5 pp., 1883,

Dimmock, George. Notes on Pterophoridæ of North America, 1 p., 1882,

- The Cocoons of Cionus scrophulariac. 4 pp., 1882,

Dyar, H. G. Notes on Two Species of Datana, with Descriptions of Their Larval Stages. 6 pp., 1890,

- Preparatory Stages of Cerura multiscripta. 3 pp., 1890,

Edwards, W. H. The Number of Molts in Butterflies, with some History of Callosamia promethea. 5 pp., 1881,

Elwes, H. J. The Argynnides of North America. 10 pp.,

Field, W. L. W. The Offspring of a Captured Female of Basilarchia proserpina. 3 pp., with plate, 1910,

Forbes, S. A. The American Plum-borer, Euzophera semifuneralis. 5 pp.,

Fernald, C. H. Note on Phoxopteris angulifasciana. 1 p., 1880,

Holland, W. J. Descriptions of New West African Lycænidæ. 8 pp., 1890,

Jones, J. M. On an Immense Flight of Small Butterflies (Terias lisa) in the Bermudas. 5 pp., 1875,

Lintner, J. A. A New Sexual Character in the Pupæ of Some Lepidoptera. 4 pp., 1883,

Morrison, H. K. Notes on White Mountain Noctuidæ. 3 pp., 1875,

Varieties of Cleora pulchraria. 3 pp., 1875,
Newcomb, H. H. Argynnis cybele Fabr. var. baal Streck., melanic, 1 p., with plate, 1910 ,

Packard, A. S. Notes on the Early Stages of Two Sphingidæ. 5 pp., 
- The Life History of Sierarctia echo. 3 pp., 1890,

Scudder, S. H. Early Spring Butterflies at the White Mountains. 4. pp., 1874,

Scudder, S. H. The Introduction of Danaida plexippus into the Pacific Islands. 4 pp., 1875,

2 pp., 1885,

Soule, C. G. Notes on the Early Stages of Some Heterocera. 11 pp.,

- Description of the Larva of Sphinx luscitiosa. 2 pp., 1888,

- Description of Egg and Larva of Apatelodes torrefacta. 2 pp., 1888,

Sprague, F. H. Notes on Butterflies of Massachusetts. 4 pp., 1879,

Thaxter, R. List of Sphingidæ taken about Newton, Mass., 2 p. 1874,

- Hibernation of Amphipyra pyramidoides. 2 pp., 1875,

Coleoptera.

Austin, E. P. Rediscovery of Cicindela limbata Say. 2 pp., 1875,

Austin, E. P. Geographical Distribution of North American Coleoptera. 7 pp., 1879,

Blanchard, F. Some Account of Our Species of Geotrupes. 8 pp.,

- Lixus rubellus Randall. 2 pp., 1876,

Dimmock, George. The Scales of Coleoptera. 25 pp., 1883,

Edwards, H. On the Localities and Habits of the Various Species of Omus. 3 pp., 1875,

Forbes, S. A. The Life Histories and Immature Stages of Some Eumolpini. 8 pp., 1884,

Gissler, C. F. The Anatomy of Amblychila cylindriformis Say. 11 pp., 1 plate, 1879,

Henshaw S. List of Coleoptera Collected in the Vicinity of Cliftondale, Mass. 4 pp., 1874,

Hubbard, H. G. Notes on the Habits of Magdalinus armicollis Say. 2 pp., 1874, 
Schwarz, E. A. List of Coleoptera Collected in Michigan in 1874, 5 pp., 1876,

Diptera.

Brauer, F. The Larvæ of Oestridæ. 6 pp., 1885,

Coquillett, D. W. The Systematic Position of the Genus Apiocera. 2 pp., 1885,

Gillette, C. P. A New Cecidomyid Infesting Box Elder. 2 pp.,

Smith, J. B. Notes on the Structure and History of Hamatobia serrata. 5 pp., 1890,

Snow, F. H. Hominivorous Habits of Chrysomyia macellaria. 4. pp., 1883,

Wheeler, W. M. Descriptions of Some New North American Dolichopodidæ. 22 pp., 1890,

Williston, S. W. The Screw-worm Fly (Chrysomyia macellaria). 3 pp., 1883,

- Collection and Preservation of Diptera. 3 pp., 1884,

\section{Hymenoptera.}

Bassett, H. A. On the History of a Cynipidous Gall-fly. 4 pp., 1889 ,

Brues, C. T. A New Species of Telenomus Parasitic on the Eggs of Tussock Moths. 2 pp., 1910,

Cockerell, T. D. A. Some Bees of the Genus Nomada from Washington State. 8 pp., 1910,

Dimmock, George. Salivary Glands in Bees. 3 pp., 1883,

Gillette, C. P. Notes on Certain Cynipidæ, with Descriptions of New Species. 14 pp., 1889,

Lintner, J. A. An Egg Parasite of the Currant Saw-fly. 4 p.p., 1883,

Weed, C. M. Biological Notes on Some North American Ichneumonidæ. 3 pp., 1888,

Wheeler, W. M. Colonies of Ants Infested with Laboulbenia formicarum. 4 pp., 1910,

Homoptera.

Van Duzee, E. P. Synonomy of the Homoptera Described by Say, Harris and Fitch. 5 pp., 1890,

- A New Species of Pediopsis. 4 pp., 1889,

Weed, C. M. Contribution to a Knowledge of the Autumn Life History of Certain Little Known Aphididæ. 12 pp.,

- Life History of Certain Little Known Aphididæ. 3 pp.,

Woodworth, C. W. Synopsis of North American Cicadidæ. 2 pp., 1888,

- On the Genus Cicadula. 2 pp., 1888, 


\section{Orthoptera.}

Scudder, S. H. Some Genera of Oedopodidæ Rescued from the Tryaxalidæ. 12 pp., 1890,

- The Note of the Katydid. 2 pp., 1875,

and Species of Forficulariæ. 5 pp.,

Neuropteroid Insects.

Banks, Nathan. Some Neuroptera from Australia. 7 pp., 1910,

Hagen, H. A. The Tarsal and Antennal Characters of the Psocidæ. 1 p., 1883,

- Notes and Descriptions of Some North American Libellulina. 5 pp., 1890,

-Two Species of Aeschna. 3 pp., 1890,

Hagen, H. A. Descriptions of Some North American Cordulina. 7 pp., 1890,

- Synopsis of the Odonata of North America. No. 1. 10 pp., 1889,

- The Female of Eutermes rippertii. 6 pp.,

Grassi, B. A Contribution Towards a Knowledge of Termites. 6 pp., 1889,

Moody, H. L. The Larva of Chauliodes. 2 pp., 1877,

Scudder, S. H. On the Structure of the Head of Atropos. 3 pp., 1877,

\section{General and Structural Entomology.}

Barrett, C. G. The Influence of Meteorological Conditions on Insect Life. 5 pp., 1883,

Dimmock, A. K. The Insects of Betula in North America. 5 pp., 1885,

- Variable Number of Molts of Insects. 2 pp., 1888,

Dimmock, George. The Trophi and Their Chitinous Supports in Gracilaria. 4 pp., 1880,

Edwards, W. H. Experiments upon the Effect of Cold Applied to Chrysalids of Butterflies. 4 pp., 1880, ippus. 1 p., 1881,

Forbes, S. A. On the Present State of Our Knowledge Concerning Contagious Insect Diseases. 10 pp., 1888,

Grote, A. R. On the Insect Fauna of the White Mountains. 2 pp., 1875, 
Mark, E. L. The Nervous System of Phylloxera. 7 pp., 1879, 20

Moody, H. L. The Mandibles of the Larva of Eros. 3 pp., 1876, $\quad .10$

Morrison, H. K. On an Appendage of the Male Leucarctia acrcea. 2 pp., 1874,

Packard, A. S. On the Occurrence of Organs, Probably of Taste, in the Epipharynx of the Mecaptera. 6 pp., 1889,

Packard, A. S. The Epipharynx and the Epipharyngeal Organs of Taste in Mandibulate Insects. 14 pp., 1889,

Scudder, S. H. The Chirp of the Mole Cricket. 2 pp., 1875, $\quad .10$

- Odoriferous Glands in Phasmidæ. 4 pp., 1876, 15

- The Work of a Decade on Fossil Insects. 9 pp., 1889, $\quad .10$

Smith, J. B. Notes on Some Aphid Structures. 6 pp., 1890, 10

Trelease, W. Myrmecophilism. 10 pp., 1889, .15

Van Duzee, E. P. Mimicry in Hemiptera. 2 pp., 1888, 05

Myriapoda and Arachnida.

Atkinson, G. F. Notes on Protective Resemblances in Spiders. 2 pp., 1888, $\quad 05$

Emerton, J. H. Spiders Common to New England and Europe. 3 pp., 1876, $\quad .10$

Scudder, S. H. The Geological History of Myriapods and Arachnids. 6 pp., 1885, 

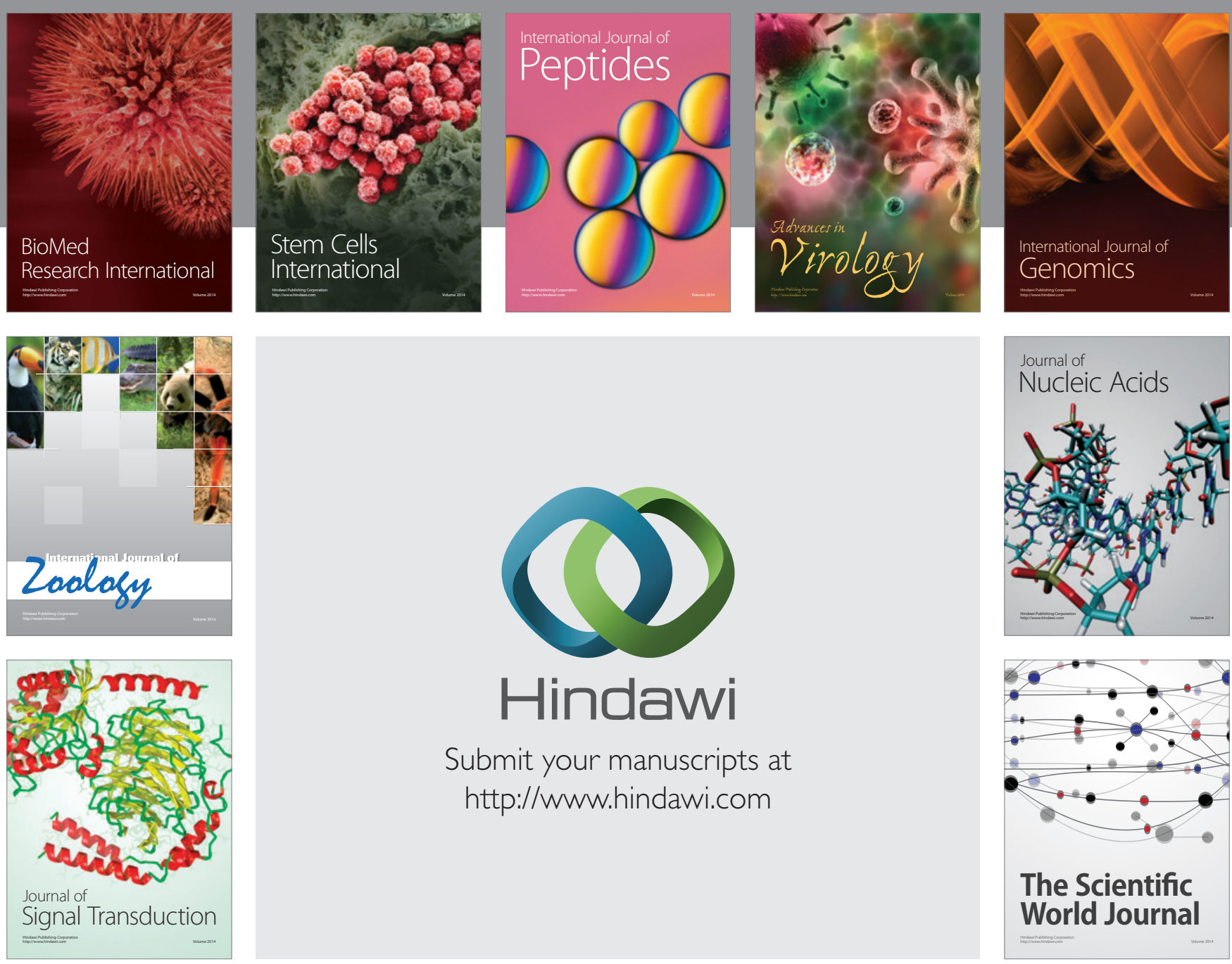

Submit your manuscripts at

http://www.hindawi.com
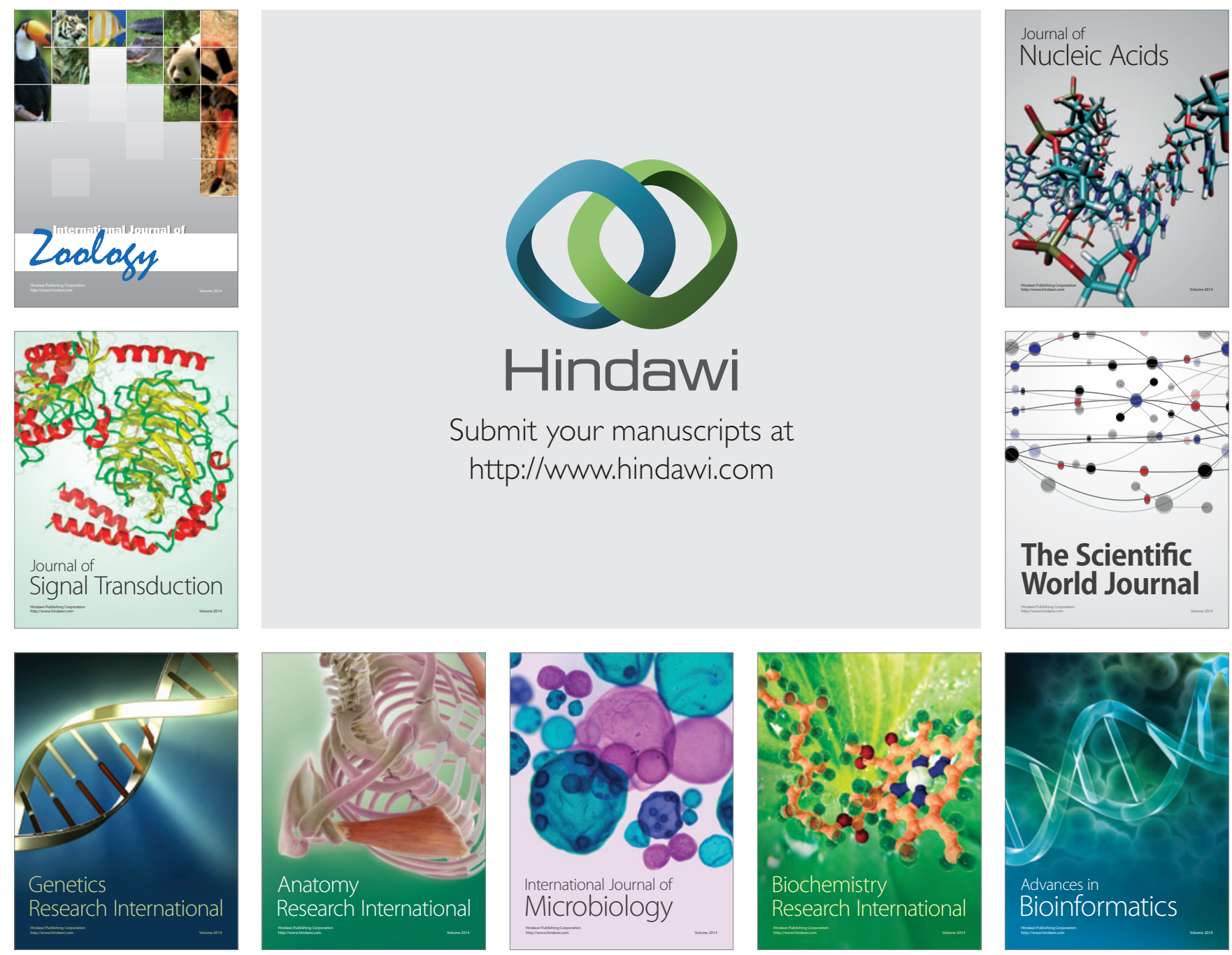

The Scientific World Journal
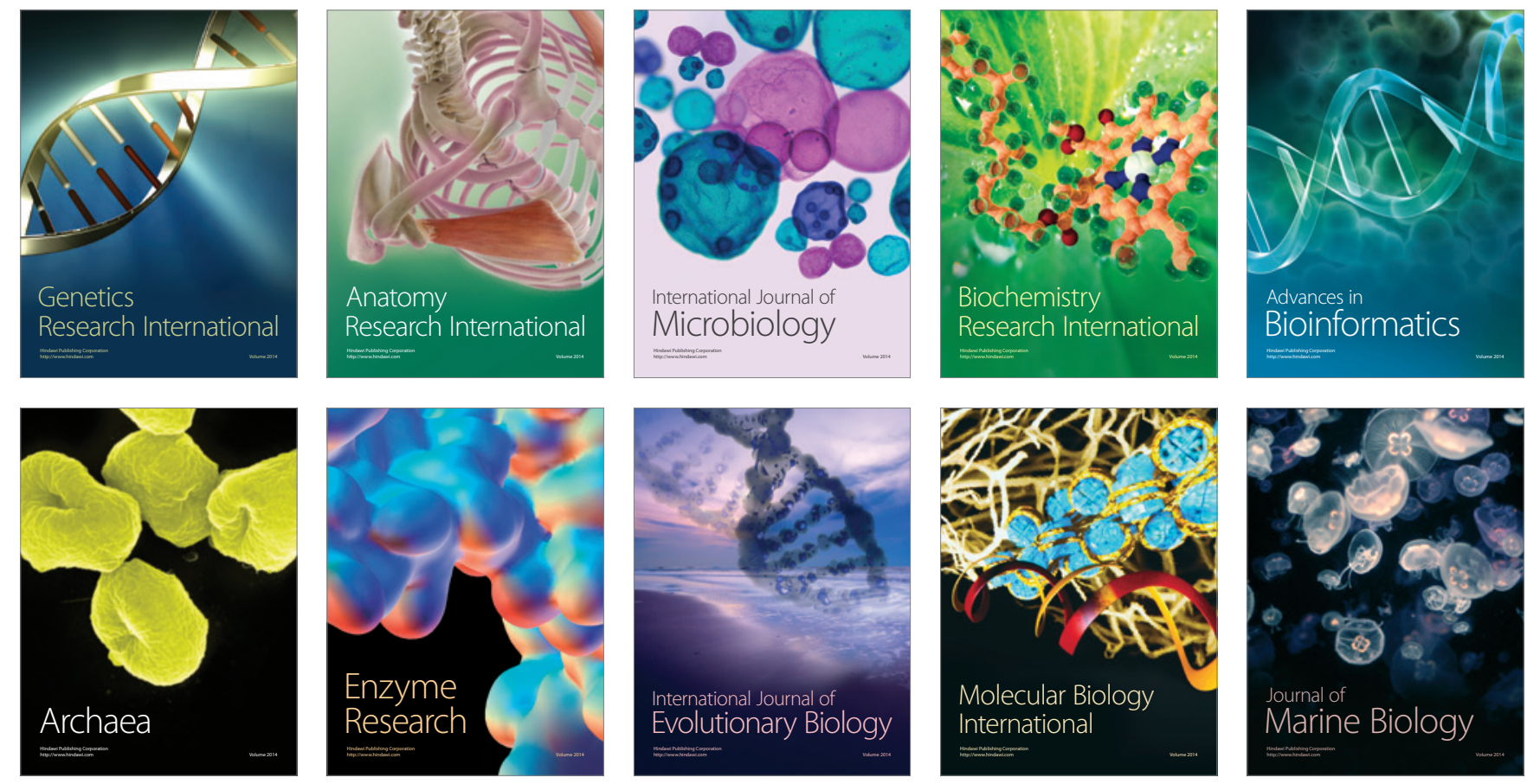